\title{
Curcumin acts as anti-tumorigenic and hormone-suppressive agent in murine and human pituitary tumour cells in vitro and in vivo
}

\author{
C Schaaf, B Shan, M Buchfelder ${ }^{1}, M$ Losa $^{2}$, J Kreutzer ${ }^{3}$, W Rachinger ${ }^{4}$, \\ G K Stalla, T Schilling ${ }^{5}, E$ Arzt $^{6,7}, M J$ Perone ${ }^{6,7}$ and U Renner
}

\author{
Neuroendocrinology Group, Max Planck Institute of Psychiatry, Kraepelinstrasse 10, D-80804 Munich, Germany \\ ${ }^{1}$ Neurosurgical Clinic, University of Erlangen-Nuremburg, Erlangen, Germany \\ ${ }^{2}$ Department of Neurosurgery, Istituto San Raffaele, Milano, Italy \\ ${ }^{3}$ Neurosurgical Clinic, Technical University of Munich, Munich, Germany \\ ${ }^{4}$ Neurosurgical Clinic, University of Munich, Munich, Germany \\ ${ }^{5}$ Department of Internal Medicine 1 and Clinical Chemistry, University of Heidelberg, Heidelberg, Germany \\ ${ }^{6}$ Laboratorio de Fisiología y Biología Molecular, Departamento de Fisiología y Biología Molecular y Celular, Facultad de Ciencias \\ Exactas y Naturales, Universidad de Buenos Aires, Pabellon II-2 Piso, C1428 Buenos Aires, Argentina \\ ${ }^{7}$ IFIBYNE-CONICET, Ciudad Universitaria, Pabellon II-2 Piso, C1428 Buenos Aires, Argentina \\ (Correspondence should be addressed to U Renner; Email: renner@mpipsykl.mpg.de; M J Perone; \\ Email: mperone@fbmc.fcen.uba.ar)
}

\begin{abstract}
Curcumin (diferuloylmethane) is the active ingredient of the spice plant Curcuma longa and has been shown to act anti-tumorigenic in different types of tumours. Therefore, we have studied its effect in pituitary tumour cell lines and adenomas. Proliferation of lactosomatotroph GH3 and somatotroph MtT/S rat pituitary cells as well as of corticotroph AtT20 mouse pituitary cells was inhibited by curcumin in monolayer cell culture and in colony formation assay in soft agar. Fluorescence-activated cell sorting (FACS) analysis demonstrated curcumin-induced cell cycle arrest at G2/M. Analysis of cell cycle proteins by immunoblotting showed reduction in cyclin $D_{1}$, cyclin-dependent kinase 4 and no change in p27 $7^{\mathrm{kip}}$. FACS analysis with Annexin V-FITC/7-aminoactinomycin D staining demonstrated curcumin-induced early apoptosis after 3 , 6,12 and $24 \mathrm{~h}$ treatment and nearly no necrosis. Induction of DNA fragmentation, reduction of $\mathrm{Bcl}-2$ and enhancement of cleaved caspase-3 further confirmed induction of apoptosis by curcumin. Growth of GH3 tumours in athymic nude mice was suppressed by curcumin in vivo. In endocrine pituitary tumour cell lines, GH, ACTH and prolactin production were inhibited by curcumin. Studies in 25 human pituitary adenoma cell cultures have confirmed the antitumorigenic and hormone-suppressive effects of curcumin. Altogether, the results described in this report suggest this natural compound as a good candidate for therapeutic use on pituitary tumours.
\end{abstract}

Endocrine-Related Cancer (2009) 16 1339-1350

\section{Introduction}

Clinically, active tumours of the anterior pituitary represent the second most frequent form of intracranial neoplasms with a prevalence of about 300 per one million inhabitants per year (Davis et al. 2001). The monoclonal pituitary tumours are mostly benign, endocrine-active or -inactive adenomas; pituitary carcinomas are extremely rare. The clinical symptoms of the tumours are caused by their space-occupying lesion (e.g. headache, visual field loss) and, in case of endocrine-active adenomas, by the excessive hormone secretion of the tumour cells (Ezzat \& Asa 2006). $\mathrm{GH}$-secreting tumours cause gigantism in children and acromegaly in adults (Chanson \& Salenave 2008). ACTH-producing adenomas induce Cushing's disease and prolactin (PRL)-releasing tumours cause the 
symptoms of hyperprolactaemia (Newell-Price et al. 2006, Mancini et al. 2008). Thyreotrophin- and gonadotrophin-producing adenomas are rare (Ezzat \& Asa 2006). A life-long pharmacological treatment with dopamine agonists (e.g. bromocriptine, cabergoline) is highly effective in prolactinomas (Mancini et al. 2008). In patients with acromegaly, treatment with somatostatin analogues (e.g. octreotide, lanreotide and pasireotide) or with the $\mathrm{GH}$ receptor antagonist (e.g. pegvisomant) normalizes the GH- and insulinlike growth factor 1 levels in about $50 \%$ of the affected patients (Chanson \& Salenave 2008). Other pituitary adenoma types and tumours from pharmacotreatmentresistant patients have to be removed by surgery. Since the latter is often not associated with complete cure of the patients, additional pharmacological concepts for the treatment of pituitary adenomas would be desirable.

It is assumed that plants contain a big reservoir of drugs with anti-tumorigenic properties (Corson \& Crews 2007), but so far only few plant-derived substances such as vincristine or paclitaxel have achieved clinical relevance as chemotherapeutic agents (Gidding et al. 1999, Fitzpatrick \& Wheeler 2003). However, during the recent years, a growing number of plant-derived drugs with anti-tumorigenic activities have been detected, one among them is curcumin (diferuloylmethane), a biphenolic natural product and the active component of turmeric (Curcuma longa), which gives Indian curry its yellow colour and distinctive taste (Aggarwal et al. 2007). Having been used as a remedy in traditional Indian medicine for centuries, curcumin has recently been identified as an anti-cancer drug in various types of cancer (Shishodia et al. 2007, Hatcher et al. 2008) but has also been demonstrated to exhibit antidepressant, anti-oxidative, anti-inflammatory and neuroprotective actions (Singh 2007). The antitumorigenic properties of curcumin involve both anti-proliferative and pro-apoptotic effects on tumour cells (Sa \& Das 2008, Shankar et al. 2008). Regarding its mechanism of action, curcumin was shown to act at multiple levels. Curcumin modified histone acetylation, which in turn affected gene expression (Kunnumakkara et al. 2008), affected cyclin and cyclin-dependent kinases (CDKs), modulated phosphatidylinositol 3 kinase (PI3K)/Akt and MAP kinase signal pathways, affected apoptotic proteins (Bcl-2 and Bax), reduced secretion of angiogenic factors and modified the expression of transcription factors (e.g. down-regulated NF- $\kappa \mathrm{B}$; Sandur et al. 2007, Barnes 2008, Carroll et al. 2008, Chadalapaka et al. 2008, Sa \& Das 2008).
Curcumin is currently tested in several phase II clinical studies for its efficacy in the treatment of various diseases such as colon and pancreatic cancers (Corson \& Crews 2007, Johnson \& Mukhtar 2007, Dhillon et al. 2008).

In a recent paper, it has been shown that curcumin inhibited proliferation, induced apoptosis and suppressed hormone secretion in the lactosomatotroph GH3 rat pituitary tumour cell line (Miller et al. 2008). The aim of the present work is to study antitumorigenic actions of curcumin in other rodent endocrine pituitary tumour cells. Moreover, we explored for the first time about the role of curcumin in vivo in experimentally induced pituitary tumours of nude mice and in primary cell cultures of human pituitary adenomas.

\section{Materials and methods}

\section{Materials}

Cell culture materials and reagents were obtained from Life Technologies, Falcon (Heidelberg, Germany), Nunc (Wiesbaden, Germany), Seromed (Berlin, Germany), Flow Cytometry Standards Corp. (Meckenheim, Germany) and Sigma. Curcumin (95\%, turmeric powder) and dimethylsulphoxide (DMSO) were purchased from Sigma.

\section{Cell culture and curcumin stimulation}

Lactosomatotroph GH3 and somatotroph MtT/S rat pituitary cells as well as corticotroph AtT20 mouse pituitary cells were cultured at $5 \% \mathrm{CO}_{2}$ and $37^{\circ} \mathrm{C}$ in DMEM (pH 7.3) supplemented with $10 \%$ FCS, 2.2 g/l $\mathrm{NaHCO}_{3}, 10 \mathrm{mM}$ HEPES and $2 \mathrm{mM}$ glutamine, $2.5 \mathrm{mg} / 1$ amphotericin $\mathrm{B}, 10^{5} \mathrm{U} / 1$ penicillin-streptomycin, $5 \mathrm{mg} / \mathrm{l}$ insulin, $5 \mathrm{mg} / \mathrm{l}$ transferrin, $20 \mu \mathrm{g} / \mathrm{l}$ sodium selenite and $30 \mathrm{pM}$ tri-iodothyronine (Henning, Berlin, Germany).

For primary human pituitary tumour cell culture, adenoma tissue was obtained by transsphenoidal surgery from 25 patients with various types of pituitary adenomas as indicated in Table 1. Dispersion of the tumour tissues and subsequent cultivation of the tumour cells were performed in the same way as for pituitary cell lines and as previously described (Renner et al. 1998). Due to the limited amount of human pituitary tumour tissue available, not all experiments could be done in parallel in primary human pituitary tumour cell cultures (see Table 1).

For in vitro experiments, a stock solution of $10 \mathrm{mM}$ curcumin (prepared in DMSO) was diluted with cell 
Table 1 Overview about human pituitary adenomas studied and results obtained after treatment with curcumin in primary cell culture

\begin{tabular}{|c|c|c|c|c|c|c|}
\hline \multirow[b]{2}{*}{ Tumour $^{a}$} & \multirow[b]{2}{*}{ Hormones } & \multirow[b]{2}{*}{ Sex/age } & \multirow[b]{2}{*}{ Proliferation $^{\mathrm{b}}$} & \multirow[b]{2}{*}{ Apoptosis ${ }^{c}$} & \multicolumn{2}{|c|}{ Hormone secretion } \\
\hline & & & & & $\%$ Inhibition $^{d}$ & Basal $^{e}$ \\
\hline \multirow[t]{2}{*}{ LST1 } & PRL & M/66 & $59.8 \pm 5.3^{\dagger}$ & ND & $65.1 \pm 6.0^{*}$ & $855.7 \pm 19.3$ \\
\hline & $\mathrm{GH}$ & $\mathrm{M} / 66$ & $59.8 \pm 5.3^{\dagger}$ & ND & $77.5 \pm 3.0^{*}$ & $1226.3 \pm 30.0$ \\
\hline LT1 & PRL & $\mathrm{F} / 60$ & ND & ND & $99.8 \pm 1.4$ & $62.6 \pm 0.3$ \\
\hline ST1 & $\mathrm{GH}$ & $\mathrm{F} / 41$ & $69.1 \pm 1.5^{\star}$ & ND & ND & ND \\
\hline ST2 & $\mathrm{GH}$ & $\mathrm{F} / 57$ & ND & ND & $77.0 \pm 4.5^{\star}$ & $1496.5 \pm 47.5$ \\
\hline ST3 & $\mathrm{GH}$ & $\mathrm{F} / 45$ & ND & ND & $60.4 \pm 8.1^{*}$ & $106.1 \pm 7.6$ \\
\hline ST4 & $\mathrm{GH}$ & $\mathrm{M} / 35$ & ND & ND & $56.5 \pm 5.2^{*}$ & $230.7 \pm 20.7$ \\
\hline ST5 & $\mathrm{GH}$ & M/32 & ND & ND & $94.0 \pm 4.9$ & $301.7 \pm 37.0$ \\
\hline ST6 & $\mathrm{GH}$ & $\mathrm{F} / 53$ & $99.0 \pm 3.5$ & ND & $88.0 \pm 0.3^{*}$ & $87.9 \pm 5.3$ \\
\hline ST7 & $\mathrm{GH}$ & $\mathrm{F} / 42$ & $61.2 \pm 1.9^{\dagger}$ & $3.19 \pm 0.09^{*}$ & $55.2 \pm 2.7^{\dagger}$ & $436.5 \pm 8.2$ \\
\hline ST8 & $\mathrm{GH}$ & $\mathrm{M} / 56$ & ND & $2.37 \pm 0.41^{*}$ & $80.1 \pm 3.1^{*}$ & $1056.5 \pm 73.2$ \\
\hline ST9 & $\mathrm{GH}$ & $M / 38$ & $16.7 \pm 5.8^{\dagger}$ & ND & $62.9 \pm 9.5^{\star}$ & $1139.1 \pm 113.0$ \\
\hline TT1 & TSH & $\mathrm{F} / 64$ & ND & ND & $60.0 \pm 2.9^{\dagger}$ & $9.80 \pm 0.32$ \\
\hline TT2 & TSH & $\mathrm{M} / 28$ & $93.3 \pm 3.8$ & ND & ND & ND \\
\hline NT1 & None & $\mathrm{M} / 70$ & $29.7 \pm 1.6^{\dagger}$ & ND & - & - \\
\hline NT2 & None & $\mathrm{F} / 72$ & $65.9 \pm 12.5^{\star}$ & ND & - & - \\
\hline NT3 & None & $\mathrm{M} / 68$ & $49.1 \pm 6.5^{\dagger}$ & $10.52 \pm 1.12^{*}$ & - & - \\
\hline NT4 & None & $\mathrm{M} / 66$ & $78.7 \pm 4.0^{*}$ & ND & - & - \\
\hline NT5 & None & $\mathrm{M} / 70$ & $78.6 \pm 11.5^{\star}$ & ND & - & - \\
\hline NT6 & None & $\mathrm{M} / 64$ & $86.3 \pm 15.2$ & ND & - & - \\
\hline NT7 & None & $\mathrm{F} / 71$ & $52.6 \pm 4.1^{\dagger}$ & $3.70 \pm 0.27^{*}$ & - & - \\
\hline NT8 & None & $\mathrm{F} / 72$ & ND & $4.45 \pm 0.47^{\star}$ & - & - \\
\hline NT9 & None & $\mathrm{M} / 55$ & $48.1 \pm 6.0^{\dagger}$ & $2.06 \pm 0.01^{*}$ & - & - \\
\hline NT10 & None & $\mathrm{M} / 41$ & $11.7 \pm 1.8^{\dagger}$ & ND & - & - \\
\hline NT11 & None & $\mathrm{M} / 51$ & $52.2 \pm 6.4^{\dagger}$ & ND & - & - \\
\hline NT12 & None & $\mathrm{M} / 70$ & $30.9 \pm 7.1^{\dagger}$ & ND & - & - \\
\hline
\end{tabular}

F, female; M, male; ND, not determined. ${ }^{\star} P<0.05 ;{ }^{\dagger} P<0.01$ versus corresponding untreated cells.

a LST, lactosomatotroph tumour; LT, lactotroph tumour; ST, somatotroph tumour; TT, thyreotroph tumour; NT, non-functioning tumour.

${ }^{\mathrm{b}}$ Maximum inhibition of $[3 \mathrm{H}]$-thymidine incorporation expressed as percentage of untreated cells $(=100 \%)$.

${ }^{\mathrm{c}}$ Apoptosis was determined by cell death ELISA and is expressed as maximum fold stimulation of apoptosis in untreated cells.

dMaximum inhibition of hormone secretion expressed as percentage of untreated cells $(=100 \%)$.

${ }^{\text {eH }}$ ormone concentration $(\mathrm{ng} / \mathrm{ml})$ in cell culture supernatants of untreated human pituitary adenoma cells after $24 \mathrm{~h}$.

culture medium to obtain concentrations of $0.5-30 \mu \mathrm{M}$ curcumin for cell treatments. During curcumin application for various time periods as indicated, light exposure was reduced as much as possible. Controls with $0.3 \%$ DMSO corresponding to the amount present in the highest curcumin dosage of $30 \mu \mathrm{M}$ were performed in each experiment to exclude effects of this solvent.

\section{In vitro proliferation assays}

To study the effects of curcumin on the proliferation of pituitary tumour cell lines and human pituitary adenoma cells, $\left[{ }^{3} \mathrm{H}\right]$ thymidine incorporation experiments were performed as previously described (Renner et al. 1995, 1998). For all murine pituitary tumour cell lines, the effect of curcumin on cell growth was confirmed by direct cell counting using a cell sizeadapted coulter counter.

\section{Colony formation assay}

The soft agar colony formation assay was used to assess the growth inhibitory effect of curcumin on GH3 cells in a three-dimensional in vitro model of cell culture. Non-pre-treated and curcumin-pretreated $(24 \mathrm{~h}, 30 \mu \mathrm{M}) \mathrm{GH} 3$ cells were seeded in soft agar. To this end, cells were suspended in $0.3 \%$ agar (noble agar, Sigma) solution consisting of $4.5 \mathrm{ml} 2 \times$ DMEM medium (Invitrogen), $4.5 \mathrm{ml}$ $1 \times$ DMEM medium and $2.25 \mathrm{ml}$ FCS. The cells were plated in triplicate in 6-well plates (Nunc) coated with $0.5 \%$ agar at the density of 8000 cells per well and maintained at $37^{\circ} \mathrm{C}$ for 14-21 days. Curcumin solution $(30 \mu \mathrm{M}, 1 \mathrm{ml}$ per well) was added to non-pre-treated and pre-treated cells on top of the agar on the first day after seeding and was then renewed every 4 days. At the end of the treatment period, colonies were stained with $0.05 \%$ thiazolyl 
blue tetrazolium bromide (Sigma) solution in $0.01 \mathrm{M}$ PBS and photographed. Colony counting was performed with a special analysing tool from SC.O Lifesciences GmbH.

\section{Experiments with athymic nude mice}

Nude mice were housed in a pathogen-free environment at the Animal House Facility of The School of Natural Sciences (FCEyN), University of Buenos Aires. Experimental tumours were induced by injecting one million GH3 cells suspended in $20 \mu \mathrm{l}$ PBS into a subdermal pouch in the flanks of adult male nude mice as previously described (Paez Pereda et al. 2003, Perez Castro et al. 2003). Curcumin treatment was started when the tumour volume had reached about $100 \mathrm{~mm}^{3}$ in size. Curcumin was dissolved in $0.5 \mathrm{M} \mathrm{NaOH}-\mathrm{PBS}$ and a total amount of $1 \mathrm{mg}$ curcumin per mouse was administered i.p., $200 \mu \mathrm{l}$ injection thrice a week. Vehicle-treated animals served as controls. The tumour volume was regularly determined as previously described (Paez Pereda et al. 2003, Perez Castro et al. 2003) until the animals were killed. The Ethical Committee on Animal Care and Use, University of Buenos Aires, Argentina had approved the animal studies.

\section{Fluorescence-activated cell sorting analysis}

Fluorescence-activated cell sorting (FACS) analysis was performed to determine the effect of curcumin on cell cycle arrest of pituitary tumour cell lines. Cells were treated for $24 \mathrm{~h}$, harvested by trypsinization and fixed in $70 \%$ ethanol at $4{ }^{\circ} \mathrm{C}$ overnight. Samples of fixed cells were resuspended and stained in PBS containing $20 \mu \mathrm{g} / \mathrm{ml}$ PI and $10 \mu \mathrm{g} / \mathrm{ml}$ RNAse A. FACS analysis of PI emission at $630 \mathrm{~nm}$ (Fl4) was performed using a Beckman Coulter (Krefeld, Germany) XL flow cytometer, and cell cycle analysis of DNA histograms was done using the Multicycle software (Phoenix Flow Systems, San Diego, CA, USA).

Apoptosis/necrosis was also assessed by FACS analysis in MtT/S and GH3 cells after treatment with 5-30 $\mu \mathrm{M}$ curcumin using Annexin V-FITC (Beckman Coulter) with commercially available kit (Beckman Coulter, IM3614). Apoptotic cells were defined as cells that stained positive for Annexin V-FITC binding on outer cell membranes, whereas 7-aminoactinomycin D (7-AAD)-positive cells were considered to be necrotic (Quinn et al. 2007). To each tube, $20 \mu \mathrm{l}$ 7-AAD, $10 \mu \mathrm{l}$ Annexin V-FITC and $100 \mu \mathrm{l} 1 \times$ Binding Buffer (Beckman Coulter) were added and incubated on ice for $15 \mathrm{~min}$ in the dark. Post incubation, $300 \mu \mathrm{l}$ $1 \times$ Binding Buffer (Beckman Coulter) was applied to each tube. Excitation was at $488 \mathrm{~nm}$, the FITC fluorescence was recorded on a fluorescence 1 (FL1) sensor (515-545 nm-BP), and the 7-AAD fluorescence was recorded on a FL4 sensor (600 nm-LP). Data analysis was performed with Coulter XL software EXPO 32.

\section{Detection of apoptosis by DNA fragmentation}

In addition to FACS analysis, DNA fragmentation as an indicator of apoptosis was measured by a cell death detection ELISA (DNA Fragmentation Kit, Roche). After seeding and $24 \mathrm{~h}$ treatment with 5-30 $\mu \mathrm{M}$ curcumin, DNA was extracted from the cells, and DNA fragmentation activity was quantified according to the manufacturer's instructions.

\section{Western blot analysis}

To study the effects of curcumin on various cell cycle regulating and apoptosis-related proteins, GH3, AtT20 and MtT/S cells were stimulated with curcumin as indicated, and after protein extraction, western immunoblotting was performed as previously described (Paez-Pereda et al. 2003). Primary antibodies for the detection of Bcl-2, caspase-3, cyclin D1, p27 ${ }^{\text {kip1 }}$ (all from Cell Signalling Tech., Beverly, MA, USA) and CDK4 (Santa Cruz Biotech., Santa Cruz, CA, USA) were made in rabbit, and anti- $\beta$-actin $\mathrm{Ab}$ (Millipore Corp., Billerica, MA, USA) was made in mouse. HRP-conjugated secondary antibodies against rabbit and mouse were all obtained from Santa Cruz Biotechnologies.

\section{Hormone stimulation and measurement}

To evaluate the effect of curcumin on hormone secretion, pituitary tumour cell lines as well as human endocrine-active adenoma cell cultures were stimulated with curcumin as indicated. ACTH, rat GH and rat PRL levels in the cell culture supernatants were analysed by RIA as described elsewhere (Stalla et al. 1989) with materials kindly provided by Dr A F Parlow from the National Hormone \& Peptide Program (Torrance, CA, USA). Human GH was measured with Immulite 2500 chemiluminescence assay (Siemens, Munich, Germany), PRL and TSH with electrochemiluminescence immunoassay (Roche).

\section{Statistical analysis}

Each of the experiments was repeated at least thrice. The individual experiments were performed with quadruplicate wells. Results were analysed by onefactorial univariate ANOVA and followed by univariate $F$ tests where appropriate. As nominal 

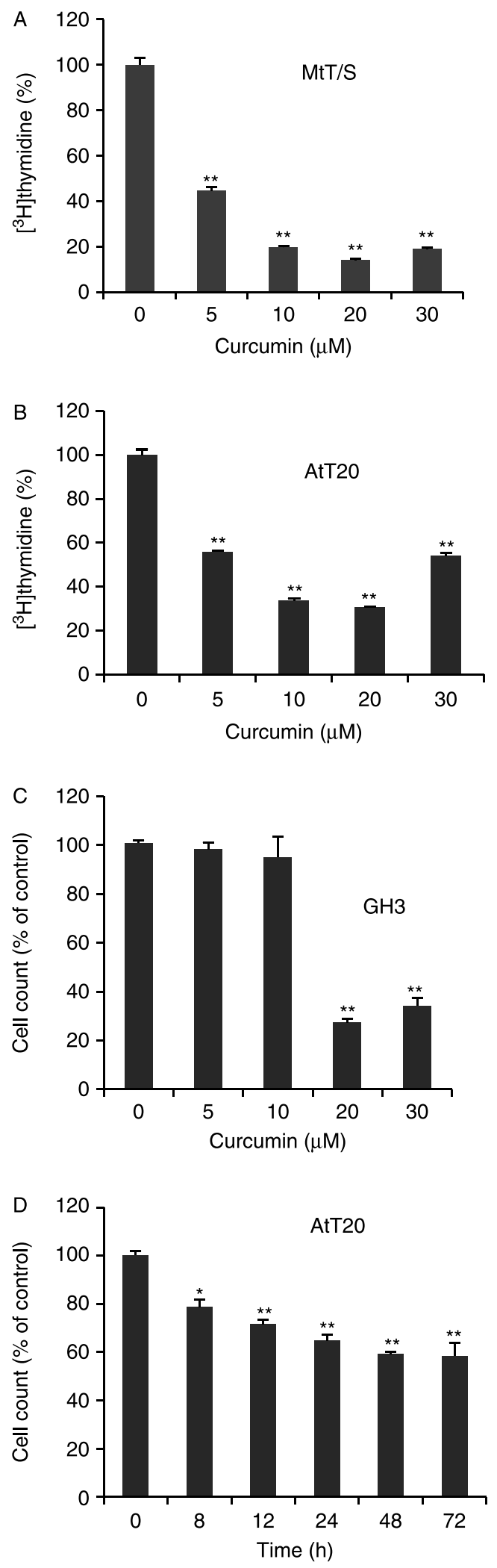

level of significance, $P=0.05$ was accepted; it was corrected (according to Bonferroni correction procedure) for all post hoc tests, in order to keep the type I error $\leq 0.05$. Data are given as mean \pm s.E.M.

\section{Results \\ Effect of curcumin on pituitary tumour cell
proliferation in vitro and in vivo}

In two in vitro proliferation assays, $\left[{ }^{3} \mathrm{H}\right]$ thymidine incorporation and determination of cell number, curcumin dose and time dependently inhibited growth of MtT/S, AtT20 and GH3 cells (Fig. 1A-D). MtT/S and AtT20 cells were most sensitive to curcumin treatment and significant growth suppression was already achieved at $5 \mu \mathrm{M}$ curcumin. The inhibitory effect of curcumin was dose-dependent and concentrations of 20 and $30 \mu \mathrm{M}$ significantly inhibited proliferation of all cell lines studied (Fig. 1A-D).

To test whether the growth inhibitory effect of curcumin is not only restricted to monolayer cell cultures, GH3 cells were used to assay the antiproliferative effect of curcumin in a three-dimensional soft agar cell culture model, which much closer than monolayer cell cultures mimic the in vivo situation. In one experiment, the cells were pre-treated with curcumin for $24 \mathrm{~h}$ to ensure maximal penetration of the cells with curcumin before seeding in soft agar, whereas, in the other experiment, GH3 cells were only treated after seeding, and thus curcumin could reach the cells in soft agar initially only by diffusion. In both the experiments, treatment with curcumin was then continued for 14 days. Curcumin dose dependently reduced the number of colonies formed in soft agar, and no difference in the degree of colony growth suppression was observed between non-pre-treated (Fig. 2A) and pre-treated (not shown) GH3 cells.

To study the inhibitory potential of curcumin on pituitary tumour progression in vivo, athymic nude mice bearing experimentally induced tumours were

Figure 1 Effect of curcumin on growth of pituitary tumour cell lines. AtT20, MtT/S and GH3 cells were treated with 5-30 $\mu \mathrm{M}$ curcumin for up to $72 \mathrm{~h}$, and effects on $\left[{ }^{3} \mathrm{H}\right]$ thymidine incorporation and cell numbers were determined. Representative figures show curcumin-induced inhibition of $\left[{ }^{3} \mathrm{H}\right]$ thymidine incorporation in MtT/S cells ((A) $24 \mathrm{~h}$ treatment) and AtT20 cells ((B) $48 \mathrm{~h}$ treatment) as well as reduction of cell numbers in $\mathrm{GH} 3$ cells ((C) $48 \mathrm{~h}$ treatment). For comparative reasons, in figures $(A),(B)$ and $(C)$, values are expressed as percentage of non-treated cells. In (D), an example of a time-course study is shown for AtT20 cells in which the gradual decline of proliferation over time after treatment with $10 \mu \mathrm{M}$ curcumin is demonstrated. For each time point, the relative decline of cell numbers of curcumin-treated versus non-treated AtT20 cells is shown. ${ }^{*} P<0.05 ;{ }^{\star \star} P<0.01$ versus non-treated cells. 
used. To this end, GH3 cells were inoculated in the flanks of nude mice and curcumin treatment was started at a tumour size of $\sim 100 \mathrm{~mm}^{3}$. In comparison to vehicle-treated animals, injection of $1 \mathrm{mg}$ curcumin per mouse/ thrice weekly induced a significant suppression of tumour size after 13 days. The difference in tumour size between vehicle- and curcumin-treated animals gradually increased until the end of the treatment period (Fig. 2B and C). Importantly, in this experiment, curcumin treatment started when the tumour volume had reached about $100 \mathrm{~mm}^{3}$ in size resembling, in some way, the situation

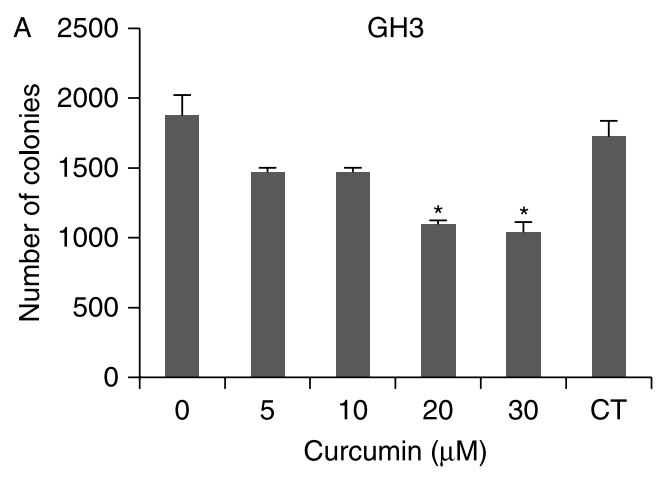

B
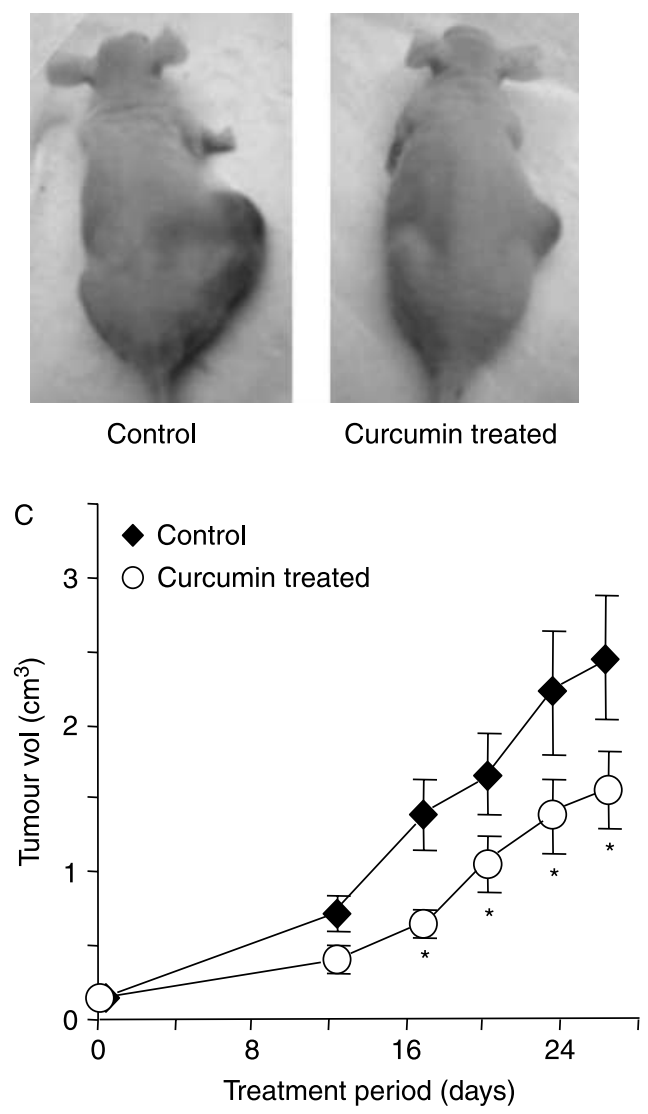

of human pituitary tumours, where clinical symptoms appeared after the tumour had reached a considerable size. These results suggest that curcumin might have therapeutic effects on pituitary tumours.

\section{Cell cycle arrest induced by curcumin treatment on pituitary tumour cell lines}

Having demonstrated the anti-proliferative effect of curcumin in pituitary tumour cells, FACS analysis was performed to determine at which phase of the cell cycle curcumin induced growth arrest on GH3 and MtT/S cells. In parallel, the expression of key cell cycle regulating proteins was measured by western immunoblotting in extracts of curcumin-treated cells. Results of FACS analysis and western immunoblotting are shown for GH3 cells (Fig. 3), but similar results have been obtained for MtT/S pituitary tumour cells (not shown). Twenty-four-hour curcumin treatment induced a dosedependent reduction in GH3 cells at G1 accompanied by an increase in cells at the G2/M phase (Fig. 3A), suggesting cell cycle arrest in G2/M phase. In extracts of GH3 cells, $24 \mathrm{~h}$ treatment with curcumin led to a down-regulation of cyclin D1 and CDK4 (Fig. 3B), which are both needed for promotion of the cells through the initial phase of G1. In contrast, expression of p2 $7^{\text {kip }}$ was not affected by curcumin (Fig. 3C).

\section{Curcumin induced apoptosis on pituitary tumour cell lines}

The observed reduction in cell numbers and tumour size after curcumin treatment (Figs 1 and 2) might not only be a consequence of suppression of proliferation, but also induction of cell death. Thus, two different methods were applied to detect apoptosis

Figure 2 Effect of curcumin on $\mathrm{GH} 3$ cell colony formation in soft agar $(A)$ and on $\mathrm{GH} 3$ cell tumour growth in nude mice (B and $\mathrm{C}$ ). (A) GH3 cells were seeded in soft agar in 6-well culture plates and treated with 5-30 $\mu \mathrm{M}$ curcumin or were not treated (0). Curcumin solutions $(1 \mathrm{ml})$ were added on the first day after seeding and were then renewed every 4 days. After 14 days, colony numbers were determined. Since curcumin solutions contained small amounts of DMSO, control cells (CT) were treated with the highest concentration of DMSO applied. Whereas the latter had no effect on colony formation, curcumin dose dependently suppressed the number of $\mathrm{GH} 3$ cell colonies. (B and C) Athymic mice bearing GH3 tumour cells were treated with curcumin for 4 weeks (1 mg per animal/ thrice weekly) or vehicle (control; six animals per group) after the tumour size has reached $100 \mathrm{~mm}^{3}$. Suppression of tumour growth by curcumin was evident after 13 days, and the difference in tumour size between curcumin- and vehicle-treated mice gradually increased over treatment time. Representative tumours on day 27 are shown in (B) and, in (C), the development of mean tumour size during the treatment period is documented. ${ }^{\star} P<0.05 ;{ }^{* \star} P<0.01$ versus non-treated cells $(\mathrm{A})$ or vehicle controls ( $\mathrm{B}$ and $\mathrm{C})$ respectively. 
A

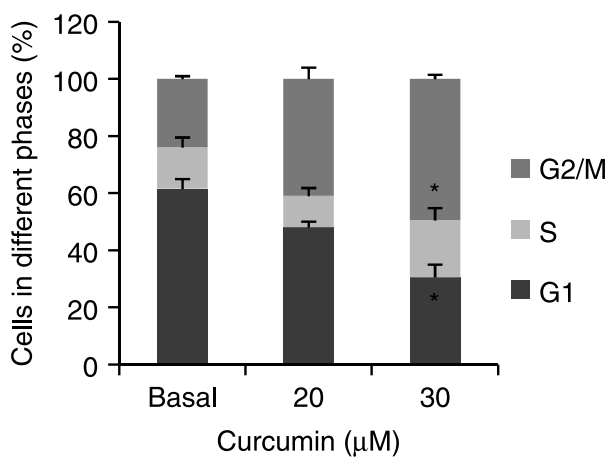

B

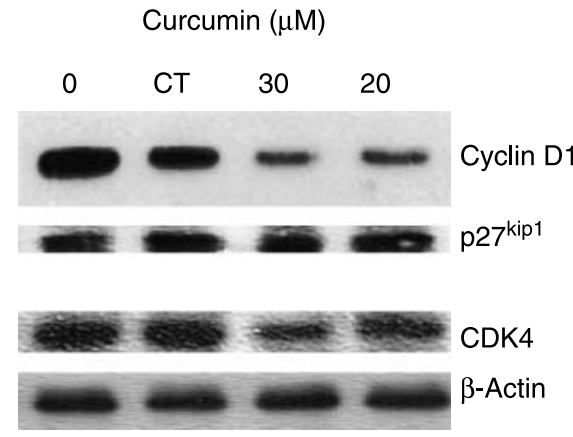

Figure 3 Effect of curcumin on the cell cycle and cell cycle regulating proteins in $\mathrm{GH} 3$ cells. After stimulation of $\mathrm{GH} 3$ cells with the indicated curcumin concentrations for $24 \mathrm{~h}$, the proportion of cells at different cell cycle phases was determined by FACS analysis (A), and alterations in the expression of cell cycle regulating proteins were measured by western immunoblotting (B). (A) Curcumin dose dependently and significantly enhanced the proportion of GH3 cells in G2/M phase and reduced cell numbers in $\mathrm{G} 1$ phase indicating a curcumininduced growth arrest in G2/M phase. (B) Studies on the effect of curcumin on key cell cycle regulating proteins showed a dose-dependent suppression of cyclin D1 and CDK4 but no effect on $\mathrm{p} 27^{\mathrm{kip} 1}$ in GH3 cells. CT, control with DMSO. ${ }^{\star} P<0.05$ versus non-treated (basal) cells.

in curcumin-treated GH3, MtT/S and AtT20 cells. Apoptosis-associated DNA degradation was measured by ELISA, and change of membrane-associated serine residues was determined by FACS analysis of Annexin V-FITC.

Curcumin $(5-30 \mu \mathrm{M})$ dose dependently increased apoptotic DNA fragmentation in all cell lines as measured by ELISA. In MtT/S cells, $30 \mu \mathrm{M}$ curcumin induced a maximum $9.57 \pm 0.71$ fold stimulation of apoptosis versus non-treated cells, whereas a 3.01 \pm 0.13 and $4.09 \pm 0.12$ fold stimulation of apoptosis was measured in GH3 and AtT20 cells respectively (in Fig. 4A, results are shown for MtT/S cells).

In AtT20, GH3 and MtT/S cells, western immunoblotting analysis showed a curcumin-induced, dose-dependent reduction in anti-apoptotic-acting $\mathrm{Bcl}-2$ and an increase in apoptosis-promoting cleaved caspase-3. In Fig. 4B, immunoblots are shown only for MtT/S cells, but similar results were obtained for AtT20 and GH3 cells (not shown).

To discriminate between curcumin-induced apoptosis and necrosis, FACS analysis was performed with $\mathrm{MtT} / \mathrm{S}$ and GH3 cells treated with $30 \mu \mathrm{M}$ curcumin for 6,12 and $24 \mathrm{~h}$, and the proportions of Annexin $\mathrm{V}$-immunopositive apoptotic and 7-AAD-immunopostive necrotic cells were measured. The results obtained for MtT/S cells (Fig. 4C) were similar to those for GH3 cells (not shown). Curcumin induced a time-dependent, significant increase in apoptotic cells accompanied by a corresponding decline in normal viable cells (Fig. 4C). No signs of necrosis in response to curcumin treatment were found indicating that curcumin has no non-specific cytotoxic effects on pituitary tumour cells. Thus, curcumin is not only suppressing proliferation but is also inducing apoptosis in pituitary tumour cells.

\section{Suppression of hormone secretion by curcumin}

Small and slowly growing, endocrine-active adenomas, e.g. corticotroph microadenomas or microprolactinomas, represent a considerable proportion of all pituitary tumours. In patients with such tumours, normalization of the excessive and pathophysiological hormone secretion is the primary therapeutic goal. When testing the hormone-suppressive activity of curcumin, we could demonstrate that curcumin significantly reduced ACTH secretion by corticotroph AtT20 cells (Fig. 5A). We could also confirm the recently reported (Miller et al. 2008) inhibitory effect of curcumin on PRL and GH secretion in GH3 cells (Fig. 5B and C). Thus, curcumin has the potential to reduce the excessive hormone production of endocrine-active pituitary tumours.

\section{Effects of curcumin on human pituitary tumour cells}

To prove the relevance of the findings obtained with rodent pituitary tumour cell lines for human pituitary adenomas, the effect of curcumin on proliferation, apoptosis and hormone production was studied in primary cell cultures of 25 human pituitary adenomas. The results are summarized in Table 1 and representative findings are shown in Fig. 6. Although human pituitary adenoma cells proliferate very slowly in culture in general, curcumin further suppressed the proliferation in 14 out of 17 human pituitary adenomas studied (Table 1; Fig. 6A and B). Measuring DNA fragmentation by cell death ELISA, a significant induction of apoptosis in response to curcumin treatment was detected in six out 


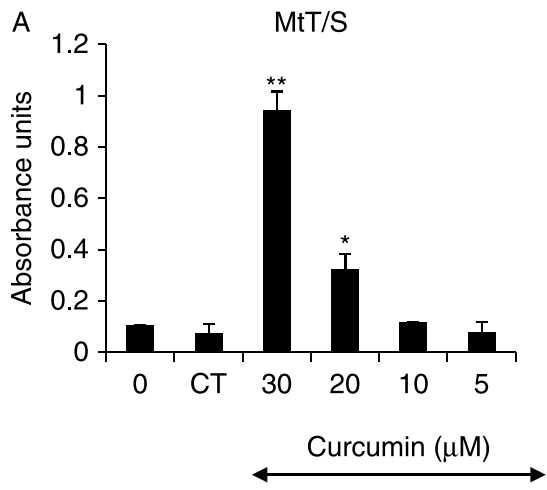

B
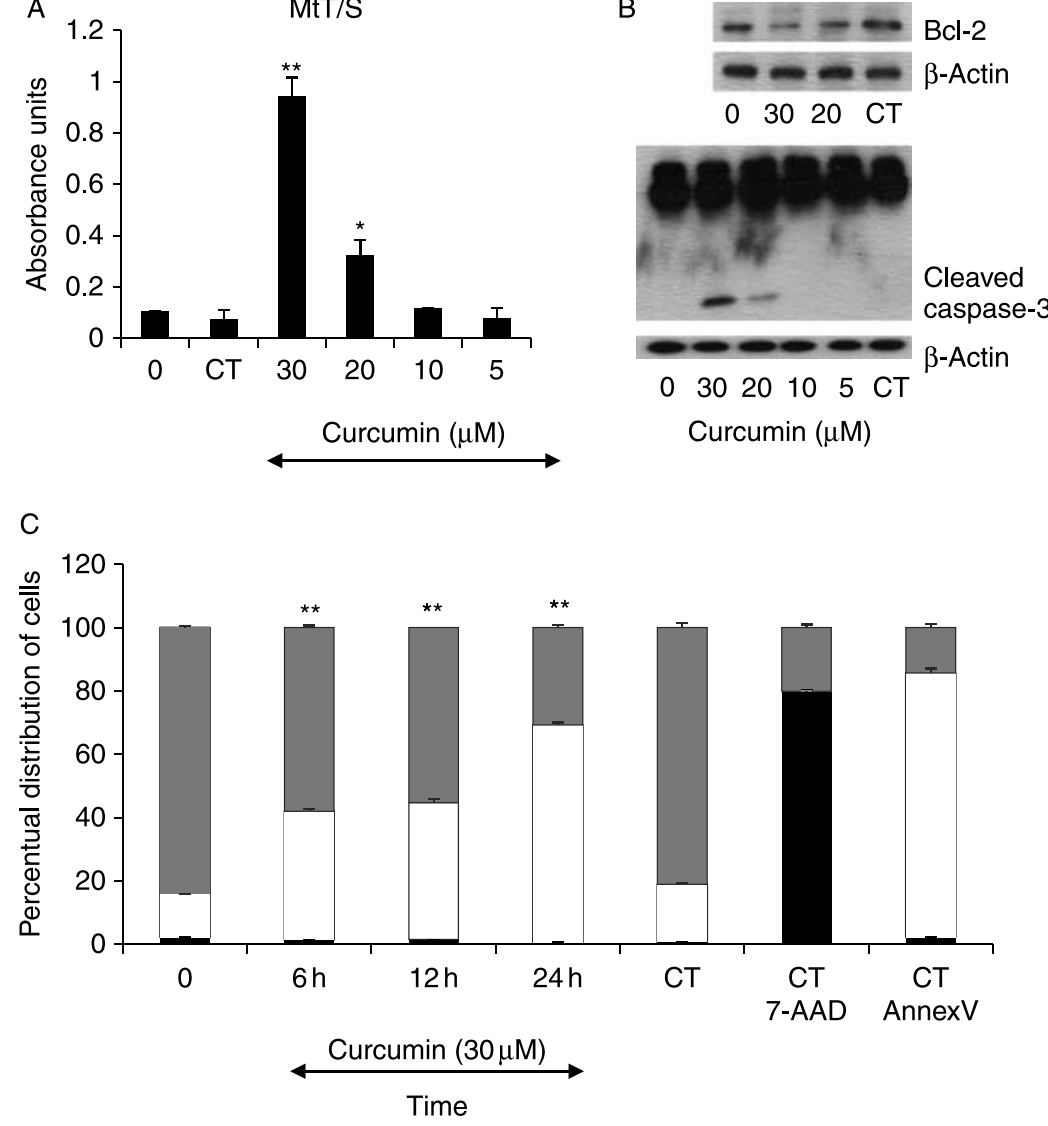

Figure 4 Effect of curcumin on apoptosis and expression of apoptosis-associated proteins in MtT/S cells. (A) Treatment of MtT/S cells with increasing concentrations of curcumin for $24 \mathrm{~h}$ induced a dose-dependent, significant increase in DNA fragmentation as measured by cell death ELISA. The application of $30 \mu \mathrm{M}$ curcumin induced a $9.57 \pm 0.71$ fold stimulation of apoptosis in comparison to non-treated MtT/S cells. (B) By western immunoblotting, it is shown that $24 \mathrm{~h}$ treatment of MtT/S cells with curcumin dose dependently suppressed the expression of anti-apoptotic-acting Bcl-2, whereas pro-apoptotic cleaved caspase-3 expression was enhanced. (C) Detection of normal (grey bars), apoptotic (white bars) and necrotic (black bars) MtT/S cells by FACS analysis after treatment with curcumin $(30 \mu \mathrm{M})$ for various time periods. Curcumin time dependently and significantly increased the proportion of cells undergoing apoptosis without any sign of induction of necrosis. Non-treated (0) and DMSO-treated (CT) cells were assayed at $24 \mathrm{~h}$ and curcumin-treated cells after indicated treatment periods. Positive controls for necrosis (CT 7-AAD) and apoptosis (CT AnnexV) were provided by the manufacturer of the FACS analysis kit. 0 , non-treated cells; $\mathrm{CT}$, control with $\mathrm{DMSO}$; ${ }^{\star} P<0.05$; ${ }^{\star \star} P<0.01$ versus non-treated cells.

of six adenomas studied (Table 1; Fig. 6C). In nine out of 11 endocrine-active human adenomas, hormone production was significantly suppressed by curcumin after stimulation periods of $4 \mathrm{~h}$ (not shown) and $24 \mathrm{~h}$ (Table 1; Fig. 6D-F). In summary, curcumin acts as antiproliferative, pro-apoptotic and hormone-suppressive agent in most, but not in all human pituitary adenomas studied.

\section{Discussion}

In the present paper, it was demonstrated for the first time that curcumin has anti-tumorigenic actions on rodent and human pituitary tumour cells in vitro and in vivo. Curcumin inhibited pituitary tumour cell proliferation and induced apoptosis in vitro and delayed pituitary tumour progression in an experimental model in vivo. Moreover, curcumin reduced hormone production in tumoural pituitary cells. The inhibitory effects of curcumin were not only observed in pituitary tumour cell lines but also to a lesser extent in primary cell cultures of human pituitary adenomas.

Curcumin has been shown to be a potent antitumorigenic agent in different types of tumours (Shishodia et al. 2007, Hatcher et al. 2008). Recently, a first study has demonstrated that curcumin acts in pituitary tumour cells since both growth and hormone production of lactosomatotroph GH3 and lactotroph MMQ cells were suppressed and apoptosis was enhanced by curcumin (Miller et al. 2008). Here, it is 
A

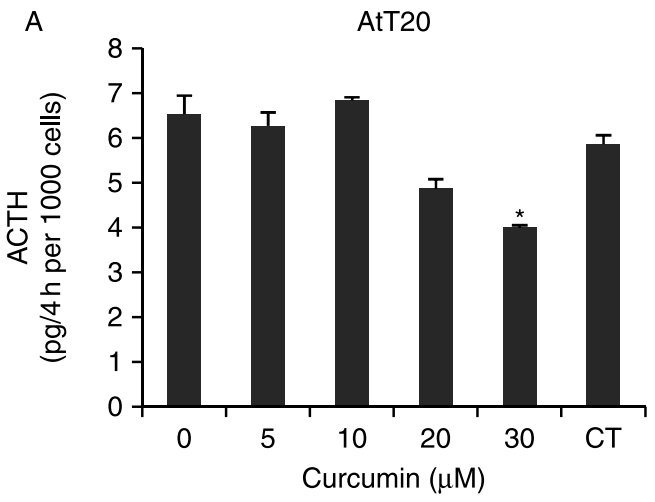

B

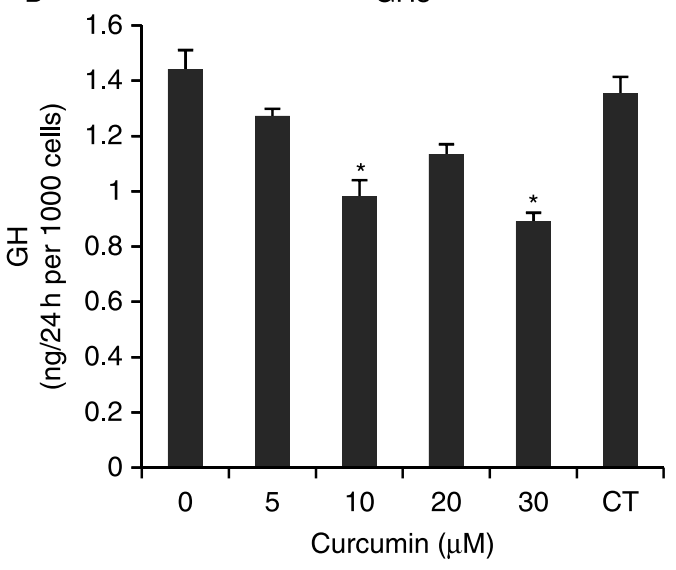

C

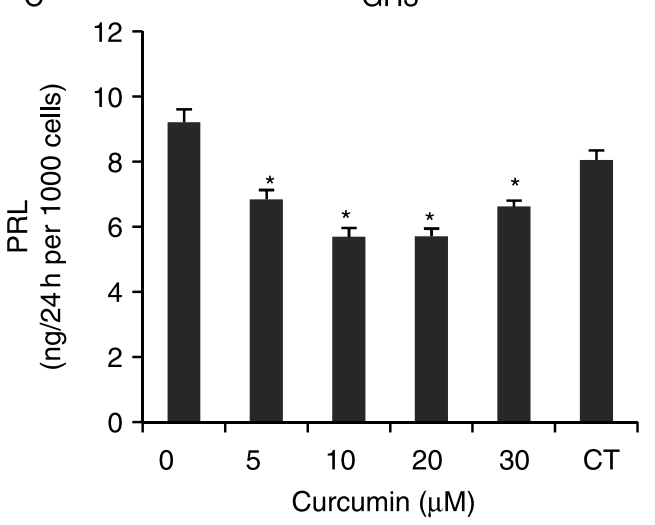

Figure 5 Effect of curcumin on hormone secretion by pituitary tumour cell lines. Corticotroph AtT20 and lactosomatotroph GH3 pituitary tumour cells were stimulated with curcumin $(5-30 \mu \mathrm{M})$ for 4 and $24 \mathrm{~h}$. At the end of the stimulation period, the cell culture supernatants were cautiously aspirated, centrifuged at $121 \mathrm{~g}$ to remove floating apoptotic cells, and then used for hormone measurement by RIA. The cells were then trypsinized and counted with an adapted coulter counter to calculate hormone production per cell. In AtT20 cells, ACTH secretion was significantly reduced by curcumin after $4(A)$ and 24 (not shown) h, at 20 and $30 \mu \mathrm{M}$ curcumin concentrations. In GH3 cells, GH and PRL were significantly reduced after 4 (not shown) and 24 (B and C) h. 0, non-treated cells; CT, controls with DMSO; ${ }^{*} P<0.05$ versus non-treated cells. shown that these effects occur not only on GH3 cells but also in other pituitary cell lines such as corticotroph AtT20 and somatotroph MtT/S cells. In these cell types, lower concentrations of curcumin as used in the study of Miller et al. were sufficient to induce significant inhibition of proliferation. Importantly, using $\mathrm{GH} 3$ cells as a representative pituitary tumour cell model, curcumin also induced suppression of tumour growth in a three-dimensional soft agar cell culture model and in experimentally induced GH3 cell tumours in nude mice in vivo.

With respect to curcumin's mechanism of action, studies in other types of tumours have shown that curcumin induces cell cycle arrest at G2/M or G1/S phases (Park et al. 2006, Srivastava et al. 2007). FACS analyses of the pituitary adenoma cell lines studied showed that curcumin treatment led to accumulation in G2/M phase of the cell cycle. This was found to be associated with curcumin-induced inhibition of cell cycle regulators such as cyclin D1 and CDK4, which are critically involved in promoting cells through the initial phase of $\mathrm{G} 1$ following $\mathrm{G} 2 / \mathrm{M}$ phase. It is likely, but still has to be proven that human pituitary adenoma cells are also arrested in G2/M. However, in contrast to rapidly growing pituitary tumour cell lines, human pituitary adenoma cells in culture grow extremely slowly and therefore, the demonstration of growth inhibition during timely limited treatment periods as well as the determination of the phase of the cell cycle, in which the growth arrest takes place, is difficult. Nevertheless, in most, but not in all human pituitary adenoma cell cultures studied, a curcumin-induced growth suppression of adenoma cells was observed.

Tumour growth arrest is often associated with induction of cell apoptosis, and in a number of different tumour cells, curcumin has been shown to induce apoptosis in parallel with growth inhibition (Cao et al. 2007, Dujic et al. 2008). Herein, we have also demonstrated that curcumin initiated apoptosis in AtT20, GH3 and MtT/S pituitary tumour cells. Even the highest concentration of curcumin did not induce necrosis in the cell lines studied indicating that curcumin has no non-specific cytotoxic effects on pituitary tumour cells. Regarding the apoptotic mechanisms, suppression of Bcl-2 and enhancement of cleaved caspase- 3 were observed in all cell lines investigated. These components are downstream modulators of different pro-apoptotic signalling pathways and therefore, it is not yet clear which of the various apoptotic signalling pathways are affected by curcumin in pituitary tumour cells. Curcumin did also induce apoptosis in six out of six human pituitary adenoma cell cultures investigated. Thus, curcumin 
A
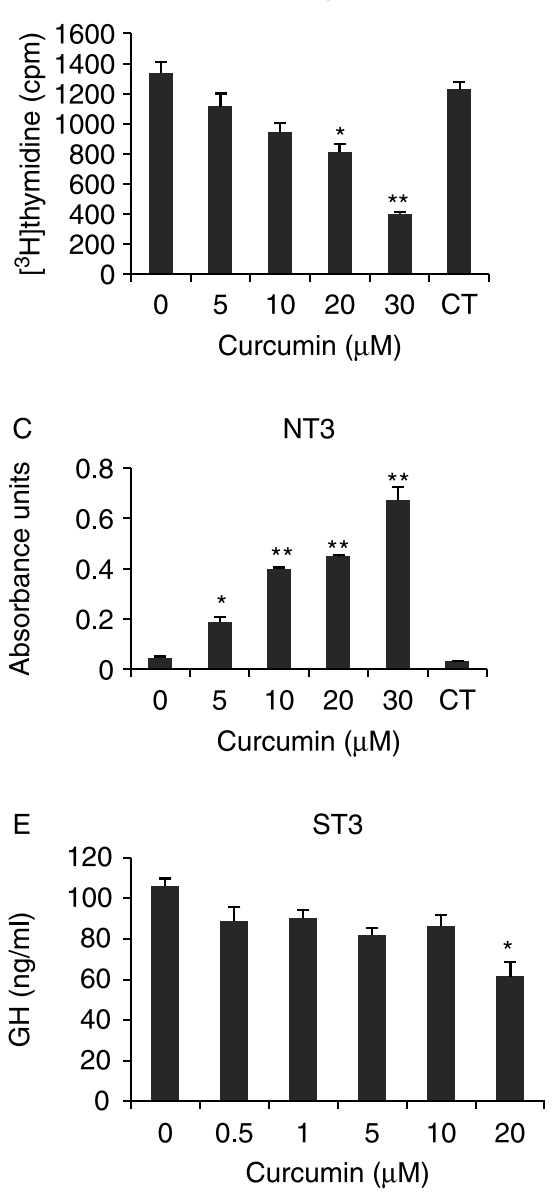

B

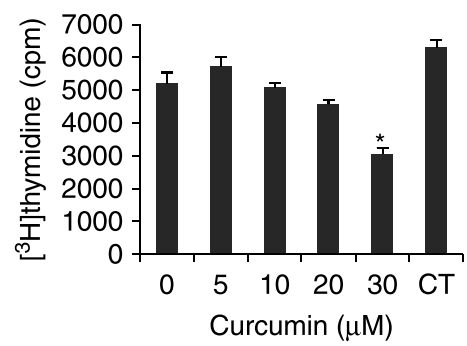

D

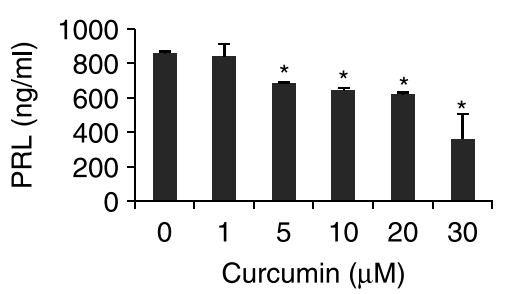

$\mathrm{F}$

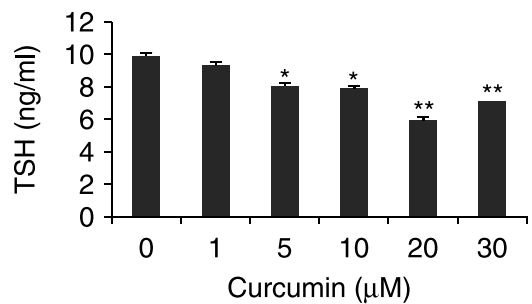

Figure 6 Effect of curcumin on human pituitary adenoma cells in vitro. Human pituitary adenoma cell cultures were treated with curcumin $(0.5-30 \mu \mathrm{M})$ and effects on growth, apoptosis and hormone secretion were measured. An overview about all studies in human pituitary tumour cell cultures is documented in Table 1. The figures presented here show dose-dependent curcumin suppression of $\left[{ }^{3} \mathrm{H}\right]$ thymidine incorporation in a non-functioning ((A) NT3) and a lactosomatotroph ((B) LST1) pituitary adenoma. Curcumin-induced apoptosis measured by cell death ELISA in a non-functioning adenoma (NT3) is shown in (C). Inhibition of GH, PRL and TSH secretion by curcumin in lactosomatotroph (LST1), somatotroph (ST3) and thyreotroph (TT1) adenomas is shown in (D), (E) and (F) respectively. In all experiments, DMSO had no effect on human pituitary adenoma cells. 0, non-treated cells; CT, controls with DMSO; ${ }^{*} P<0.05 ;{ }^{* *} P<0.01$ versus basal.

would not only stop expansion of pituitary tumours through its anti-proliferative action but would also induce tumour shrinkage, which is one of the major goals to be achieved by pharmacological treatment of pituitary macroadenomas. However, in vivo studies are needed to demonstrate shrinkage of pituitary adenomas during curcumin treatment.

Curcumin only reduced tumour progression but did not completely block GH3 cell tumour expansion in nude mice in vivo. One explanation could be that GH3 cell tumours have a high proliferative index and a dense intratumoural vessel system (Perez Castro et al. 2003), and thus expand too rapidly to be sufficiently blocked by curcumin. In contrast, in slowly growing human pituitary adenomas, which normally have a proliferation index below 1\% (Ezzat \& Asa 2006) and are poorly vascularized, curcumin may more effectively suppress tumour expansion and may even induce tumour shrinkage, but corresponding studies are needed to prove this. Another limitation on the action of curcumin in nude mice may be explained by its poor bioavailability due to its rapid degradation in vivo. Similarly as shown here, curcumin has been demonstrated to act anti-tumorigenic in many different types of tumours, but the effective dosages needed seem to be high and can only be achieved in vitro (Anand et al. 2007). It is difficult or impossible to reach such effective concentrations in vivo, due to the rapid degradation and excretion of curcumin in liver and kidney respectively (Anand et al. 2007). Therefore, effective dosages of 
curcumin may have only transiently been achieved within $\mathrm{GH} 3$ tumours bearing nude mice. Recently, efforts have been started to construct curcumin derivatives with higher stability and better bioavailability (Bisht et al. 2007, Pae et al. 2008), which may allow better treatment of curcumin-sensitive tumours, among them pituitary adenomas, in the future.

Suppression or at best normalization of hormone secretion is the principal goal in endocrine-active microadenomas (corticotroph tumours and microprolactinomas). However, nearly nothing is known about the effect of curcumin on anterior pituitary hormone production. Only recently, suppression of GH and PRL by curcumin has been demonstrated in GH3 and MMQ pituitary tumour cells (Miller et al. 2008). Here the suppressive effect on hormone secretion by GH3 cells was confirmed and moreover, an inhibitory effect on ACTH release by AtT20 cells was also shown. Although the mechanism of action through which curcumin influences hormone production is not known, the ability of curcumin to modify histone acetylation/deacetylation might play a role. Recently, histone $\mathrm{H} 4$ deacetylation of the POMC locus has been suggested to play a role in the pathophysiology of Cushing's disease (Bilodeau et al. 2006) and thus, future studies are needed to clarify whether the inhibitory action of curcumin on hormone synthesis involves histone modification. Curcumin also suppressed PRL, GH and TSH secretion in most endocrine-active human pituitary adenomas in culture suggesting a possible therapeutic role of curcumin in the treatment of hormone excess in patients with endocrineactive pituitary tumours.

In summary, the data of the present work show that curcumin has anti-proliferative, pro-apoptotic and hormone-suppressive actions on pituitary tumour cells. These effects were not only observed in pituitary tumour cell lines in vitro and in vivo but also, to a lesser extent, in human pituitary adenoma cells. Therefore, curcumin alone or in combination with already used drugs may represent a promising tool for the development of new pharmacological treatment concepts of pituitary tumours.

\section{Declaration of interest}

The authors declare that there are no conflicts of interest.

\section{Funding}

This research did not receive any specific grant from any funding agency in the public, commercial or not-forprofit sector.

\section{References}

Aggarwal BB, Sundaram C, Malani N \& Ichikawa H 2007 Curcumin: the Indian solid gold. Advances in Experimental Medicine and Biology 595 1-75.

Anand P, Kunnumakkara AB, Newman RA \& Aggarwal BB 2007 Bioavailability of curcumin: problems and promises. Molecular Pharmacology 4 807-818.

Barnes PJ 2008 Role of HDAC2 in the pathophysiology of COPD. Annual Reviews in Physiology 71 451-464.

Bilodeau S, Vallette-Kasic S, Gauthier Y, Figarelle-Branger D, Brue T, Berthelet F, Lacroix A, Batista D, Stratakis C, Hanson J et al. 2006 Role of Brg1 and HDAC2 in GR trans-repression of the pituitary POMC gene and misexpression in Cushing disease. Genes and Development 20 2871-2886.

Bisht S, Feldmann G, Soni S, Ravi R, Karikar C \& Maitra A 2007 Polymeric nanoparticle-encapsulated curcumin ("nanocurcumin"): a novel strategy for human cancer therapy. Journal of Nanobiotechnology 5 1-18.

Cao J, Liu Y, Jia L, Zhou HM, Kong Y, Yang G, Jiang LP, Li QJ \& Zhong LF 2007 Curcumin induces apoptosis through mitochondrial hyperpolarization and mtDNA damage in human hepatoma G2 cells. Free Radical Biology \& Medicine 43 968-975.

Carroll CE, Ellersieck MR \& Hyder SM 2008 Curcumin inhibits MPA-induced secretion of VEGF from T47-D human breast cancer cells. Menopause 15 570-574.

Chadalapaka G, Jutooru I, Chintharlapalli S, Papineni S, Smith R III, Li X \& Safe S 2008 Curcumin decreases specificity protein expression in bladder cancer cells. Cancer Research 68 5345-5354.

Chanson P \& Salenave S 2008 Acromegaly. Orphanet Journal of Rare Diseases 317.

Corson TW \& Crews CM 2007 Molecular understanding and modern application of traditional medicines: triumphs and trials. Cell 130 769-774.

Davis JR, Farrell WE \& Clayton RN 2001 Pituitary tumours. Reproduction 121 363-371.

Dhillon N, Aggarwal BB, Newman RA, Wolff RA, Kunnumakkara AB, Abbruzzese JL, Ng CS, Badmaev V \& Kurzrock R 2008 Phase II trial of curcumin in patients with advanced pancreatic cancer. Clinical Cancer Research 14 4491-4499.

Dujic J, Kippenberger S, Ramirez-Bosca A, Diaz-Alperi J, Bereiter-Hahn J, Kaufmann R, Bernd A \& Hofmann M 2008 Curcumin in combination with visible light inhibits tumor growth in a xenograft tumor model. International Journal of Cancer 124 1422-1428.

Ezzat S \& Asa SL 2006 Mechanisms of disease: the pathogenesis of pituitary tumors. Nature Clinical Practice. Endocrinology and Metabolism 2 220-230.

Fitzpatrick FA \& Wheeler R 2003 The immunopharmacology of paclitaxel (Taxol), docetaxel (Taxotere), and related agents. International Immunopharmacology 3 1699-1714. 
Gidding CE, Kellie SJ, Kamps WA \& de Graaf SS 1999 Vincristine revisited. Critical Review in Oncology and Hematology 29 267-287.

Hatcher H, Planalp R, Cho J, Torti FM \& Torti SV 2008 Curcumin: from ancient medicine to current clinical trials. Cellular and Molecular Life Sciences 65 1631-1652.

Johnson JJ \& Mukhtar H 2007 Curcumin for chemoprevention of colon cancer. Cancer Letters 255 170-181.

Kunnumakkara AB, Anand P \& Aggarwal BB 2008 Curcumin inhibits proliferation, invasion, angiogenesis and metastasis of different cancers through interaction with multiple cell signaling proteins. Cancer Letters 269 199-225.

Mancini T, Casanueva FF \& Giustina A 2008 Hyperprolactinemia and prolactinomas. Endocrinology and Metabolism Clinics of North America 37 67-99.

Miller M, Chen S, Woodliff J \& Kansra S 2008 Curcumin (diferuloylmethane) inhibits cell proliferation, induces apoptosis, and decreases hormone levels and secretion in pituitary tumor cells. Endocrinology 149 4158-4167.

Newell-Price J, Bertagna X, Grossman AB \& Nieman LK 2006 Cushing's syndrome. Lancet 367 1605-1617.

Pae HO, Jeong SO, Kim HS, Kim SH, Song YS, Kim SK, Chai KY \& Chung HT 2008 Dimethoxycurcumin, a synthetic curcumin analogue with higher metabolic stability, inhibits NO production, inducible NO synthase expression and NF- $\kappa \mathrm{B}$ activation in RAW264.7 macrophages activated with LPS. Molecular Nutrition \& Food Research 52 1082-1091.

Paez-Pereda M, Giacomini D, Refojo D, Nagashima AC, Hopfner U, Grubler Y, Chervin A, Goldberg V, Goya R, Hentges ST et al. 2003 Involvement of bone morphogenetic protein 4 (BMP-4) in pituitary prolactinoma pathogenesis through a Smad/estrogen receptor crosstalk. PNAS 100 1034-1039.

Park C, Kim GY, Kim GD, Choi BT, Park YM \& Choi YH 2006 Induction of G2/M arrest and inhibition of cyclooxygenase- 2 activity by curcumin in human bladder cancer T24 cells. Oncology Reports 15 1225-1231.

Perez Castro C, Giacomini D, Carbia Nagashima A, Onofri C, Graciarena M, Kobayashi K, Paez-Pereda M, Renner U, Stalla GK \& Arzt E 2003 Reduced expression of the cytokine transducer gp130 inhibits hormone secretion, cell growth, and tumor development of pituitary lactosomatotrophic GH3 cells. Endocrinology 144 693-700.

Quinn J, Fisher P, Capocasale R, Achuthanandam R, Kam M, Bugelski P \& Hrebien L 2007 A statistical pattern recognition approach for determining cellular viability and lineage phenotype in cultured cells and murine bone marrow. Cytometry 71 612-624.

Renner U, Newton CJ, Pagotto U, Sauer J, Arzt E \& Stalla GK 1995 Involvement of interleukin-1 and interleukin-1 receptor antagonist in rat pituitary cell growth regulation. Endocrinology 136 3186-3193.

Renner U, Arzberger T, Pagotto U, Leimgruber S, Uhl E, Muller A, Lange M, Weindl A \& Stalla GK 1998 Heterogeneous dopamine D2 receptor subtype messenger ribonucleic acid expression in clinically nonfunctioning pituitary adenomas. Journal of Clinical Endocrinology and Metabolism 83 1368-1375.

Sa G \& Das T 2008 Anti cancer effects of curcumin: cycle of life and death. Cell Division 314

Sandur SK, Ichikawa H, Pandey MK, Kunnumakkara AB, Sung B, Sethi G \& Aggarwal BB 2007 Role of pro-oxidants and antioxidants in the anti-inflammatory and apoptotic effects of curcumin (diferuloylmethane). Free Radical Biology \& Medicine 43 568-580.

Shankar S, Ganapathy S, Chen Q \& Srivastava RK 2008 Curcumin sensitizes TRAIL-resistant xenografts: molecular mechanisms of apoptosis, metastasis and angiogenesis. Molecular Cancer 716.

Shishodia S, Chaturvedi MM \& Aggarwal BB 2007 Role of curcumin in cancer therapy. Current Problems in Cancer 31 243-305.

Singh S 2007 From exotic spice to modern drug? Cell 130 $765-768$.

Srivastava RK, Chen Q, Siddiqui I, Sarva K \& Shankar S 2007 Linkage of curcumin-induced cell cycle arrest and apoptosis by cyclin-dependent kinase inhibitor p21(/WAF1/CIP1). Cell Cycle 6 2953-2961.

Stalla GK, Stalla J, von Werder K, Muller OA, Gerzer R, Hollt V \& Jakobs KH 1989 Nitroimidazole derivatives inhibit anterior pituitary cell function apparently by a direct effect on the catalytic subunit of the adenylate cyclase holoenzyme. Endocrinology 125 699-706. 